\title{
Community understanding of the impact of temporary visitors on incidental destinations
}

\author{
Ken Simpson and Phil Bretherton
}

\begin{abstract}
Influential changes in global economics have posed important survival and sustainability questions for small urban communities. In response, many such communities have turned to the tourism industry as a potential economic saviour, and have thus embarked on a developmental journey that has been exhaustively examined in the tourism literature of the past thirty years. However, this literature is all but unanimous in examining the benefits and costs of community tourism after the event, when those costs and benefits have become clearly evident and significantly entrenched. In seeking to evaluate the extent to which residents of four small cities are aware of potential costs and benefits, before the advent of any significant tourism activity, this paper analyses the content of 782 responses to a written survey procedure. Results indicate a generally realistic local awareness of the economic aspects of increased tourism activity, but an over-optimistic assessment of environmental impacts, societal impacts, and the ability of local stakeholders to successfully manage the process of tourism industry development.
\end{abstract}

Keywords: parks; recreation; leisure; regional development; citizen participation; local governance; tourism/recreation

There are no evil monsters ... there are only humans who think, feel, and act irrationally, sometimes out of confusion, sometimes out of insecurity (Switzer, 2001)

In commenting on Nobel prize-winner J.M. Coetzee’s 1980 novel "Waiting for the Barbarians," Chris Switzer highlights the degree to which human beings are typically able to maintain an enhanced level of positivity in the prelude to an anticipated event.

Particularly in environments that are perceived as less than optimal, we have all experienced a conviction that somehow things will get better-when the government changes, when the weather improves, or when we acquire a higher level of qualification. The unifying feature in all of these situations is a somewhat irrational belief that the future unknown will necessarily be an improvement on the currently known - that the grass of the future will inevitably be greener than the grass of the present.

To some extent, this is the promise of community development for, as Theodori (2005, p. 662) has aptly observed, "time and again, community development has been prescribed as a popular means of improving the social, economic, and environmental quality of life for residents of a community.' In order to achieve this ambition, there is an inevitable process of optimistic futurism associated with the community development model, in which multiple strands of potential quality of life improvement are presented to community residents as an enticement to take part in some form of programmed behavior change. As Theodori goes on to say, however, this admirable objective can often founder through a lack of understanding of what "community"' actually is, and an imperfect knowledge of the processes necessary to transform a theoretical model into a practical outcome.

In this respect, there are significant parallels and overlaps with many of the well established principles that populate the tourism literature. Just as community development continues to promise improvement in societal, economic, and environmental conditions, so the gradual evolution of paradigmatic thinking in relation to a burgeoning tourism industry has arrived at a conclusion that true sustainability in tourism development (if, indeed, there is such a thing) can only be realised in circumstances where economic, societal, and environmental implications are taken into account (Weaver \& Lawton, 2002). These coincidental streams of reasoning have found an outlet for their expression in the concept of 
community-based tourism, the process by which the principles and practices of domestic and/or international tourism are used as a vehicle to facilitate local community development (Addison, 1996).

The basic premise of a tourism-based model of community development is that sustainable improvements in economic, societal, and environmental conditions can be realised in situations where a local community is actively involved in the design, implementation, management, and review of its own local visitor industry (Fleischer \& Felsenstein, 2000). In this context, “active involvement”' implies that local citizens will participate in the process of opportunity identification and evaluation (Sautter \& Leisen, 1999), the design of an overarching policy and strategy (Bramwell \& Sharman, 1999), the operational monitoring of visitor industry activities (Hardy \& Beeton, 2001), and the mitigation of any negative outcomes that arise (Choi \& Sirakaya, 2006). Indeed, there are a significant number of instances in which this process has been at least superficially undertaken, and a catalogue of common benefits and costs has emerged as a result (Zhang, Inbakaran, \& Jackson, 2006).

Again reflecting the principles of both community development and tourism management, these benefits and costs have traditionally been presented as a triad of economic, societal, and environmental impacts. Though the scope and scale of impact is thought to continuously evolve in response to changing patterns of visitor volumes, tourist types, and activities undertaken, there is a well-supported view that tourism offers substantial (though selectively distributed) economic benefits to a community, often severe and sometimes debilitating environmental costs, and something of a mixed bag of both positive and negative societal adjustments (Hall \& Lew, 1998). From this perspective then, appropriate management of any community venture into tourism appears extremely desirable, as does an improved understanding of the ways in which community tourism is thought to develop.

However, it is important to note that the majority of these evolutionary processes have been described in retrospect. In other words, there has been a predominant focus on determining the overall costs and benefits of tourism development after the event, when it may well be too late to seek any real adjustment to the policies and processes by which benefits are accrued and distributed; and certainly too late to avoid the apparently inevitable negatives that are thought to accompany such economic improvements. Thus, the literature has been much more effective in identifying " what went wrong”' than it has been in equipping communities with the strategies necessary to anticipate and adapt to the dangers that are predicted to lie ahead.

In an attempt to address this anomaly, this paper initially reviews the theoretical propositions that have emerged from thirty years of academic investigation into the development of tourism in high-profile destination areas, concluding that a broadly predictable model of community tourism development can readily be isolated and described. The paper then applies the principles that underpin that model to a range of communities in which tourism has yet to fully establish itself. Introducing the concept of "incidental destinations,"' the paper seeks to measure the extent to which those communities have reached an accurate understanding of the implications of visitor activity, and the extent to which this understanding translates to a level of support for (or opposition to) future visitor industry developments.

In pursuit of this goal, a parallel program of research activity was undertaken in four small city communities in England, Ireland, Australia, and New Zealand, in an effort to establish the degree to which these communities might have absorbed the experiences of 
those who have already progressed much further along the tourism development continuum. The outcomes of this research are therefore expected to be of interest to all members of such early-stage tourism development communities, but more specifically those who are entrusted with the responsibility of delivering maximum economic benefits alongside minimized environmental and/or social side effects.

\section{Tourism-based community development}

The previously posited parallels and overlaps between community development (CD) and tourism management (TM) suggest that both bodies of knowledge may well have relevant contributions to make to any consideration of tourism-based community development. From a broader CD perspective, authors such as Di Stefano (2004) have acknowledged the underlying need to build a sustainable future for communities through attention to the aforementioned triad of developmental perspectives, and a number of alternative drivers for this type of development have been identified - encompassing a range of disparate economic engines such as science and technology (Hommen, Doloreux, \& Larsson, 2006), the arts (Phillips, 2004), clothing and textiles (Marcinczak \& van de Velde, 2008), and the so called “knowledge economy” (Yigitcanlar \& Velibeyoglu, 2008). However, irrespective of the specific economic driver selected, a clear unifying element for the community development process is the need to ensure that as wide a range of community stakeholders as possible is involved in the design and implementation of that process.

Indeed, the powerful emphasis that the CD literature has traditionally placed on the empowerment of communities and their residents is regarded as a fundamental condition of ultimate success. In this paradigm, recognition of citizen concerns around economics, societal issues, and environmental purity, and the establishment of a process that supports citizen control of the decisions related to these concerns, is fundamental—and intended developments that are undertaken without the wholehearted participation and support of the community concerned are almost certainly destined to fail. As Simpson (2007, p. 186) has commented, in relation to tourism-based community development, the key challenge is to “develop economically viable enterprises that provide livelihood benefits to local communities while protecting indigenous cultures and environments.",

Some researchers working in the CD field have however seen a need to question the ability, and indeed the desire, of tourism industry advocates to meet the essential benchmark conditions necessary to breathe life into a tourism-based CD initiative. For example, Blackstock (2005) has cast doubt on the ability of tourism to provided any meaningful or lasting benefit to the local communities that succumb to its appeal, noting that much of the thrust of the community-based tourism literature can be seen as an attempt to legitimise the business of tourism in the eyes of community, rather than to maximise the cost-benefit equation from a community resident perspective. Similarly, de Beer \& Marais (2005) point to a fundamental tension between CD's desire to maximise community prosperity and TM's focus on creating shareholder wealth. For these authors, rather than achieving the claimed partnership between community stakeholders and commercial interests, the typical community involvement initiative can often be little more than an elaborate public relations exercise.

Yet there have been instances where the interests of CD and tourism have apparently coincided. Di Stefano (2004) cites the example of Whitefish, Montana, a town that responded to the gradual decline of traditional industry by introducing a new, and highly successful, visitor industry based on winter sports; and Gotham (2005) points to the invaluable contribution made by tourism to the transformation of New Orleans from a regionally to a globally recognized and respected city. Thus, there are clearly evident 
positives and negatives associated with a move into tourism-based community development, and the extent to which these elements are influential has become a frequent topic of discussion in the tourism literature.

In the early literature on tourism development, a so-called " advocacy” approach prevailed, in which the relatively new commercial activity of tourism was presented as a pollution free alternative to declining primary and extractive industry. From this perspective, Page (2003) notes that the introduction of a new local tourism industry held the promise of significant income generation and employment creation, along with an encouragement of increased entrepreneurial behavior across a more equitably balanced portfolio of economic activity. Similarly, tourism was held to be largely beneficial to the local society, introducing enhanced levels of sophistication to the local culture, providing an impetus for the creation of new infrastructure which was subsequently accessible by local people, and leading to an expanded range of recreational facilities available to all. Even environmental impacts were seen in a positive light, visitors being held responsible for a range of “clean-up'” exercises intended to present the character of the destination in the most favorable way possible.

As academic consideration of tourism's influence intensified, a more cautionary approach emerged in the literature, as researchers began to uncover the reverse side of the tourism coin. Page (2003) goes on to say that the economic transformation wrought by tourism could potentially result in an over-dependence on visitors as a sole source of income, a subsequent exposure to what might well prove to be a highly seasonal activity, a high level of financial leakage outside of the community to pay for necessary imports and repatriation of corporate profits, and the introduction of inflationary pressures to real estate and commodity markets. From a societal perspective, a high influx of visitors could lead to the exclusion of local people from traditional open-access sites and activities, the commodification of local culture to meet the time-poor requirements of transient visitors, and higher levels of socially undesirable and often criminal practices (Pearce, 1989). Finally, the enormous potential for environmental destruction was belatedly conceded, and a highly negative ecological cost-benefit equation established. Tourism was now seen to indeed be a viable alternative, but pollution-free it certainly was not- Table 1 below summarizes the contradictory nature of these observations.

Identification of these conflicting issues has largely resulted from research carried out in highly tourism-intensive environments like the Hawaiian Islands (Liu \& Var, 1986), the city of York, England (Snaith \& Haley, 1999), the Gold Coast region of Australia (Tomljenovic \& Faulkner (1999), and the Mediterranean island of Cyprus (Akis, Peristianis, \& Warner, 1996). In these and similar cases, the level of tourism development, socio-cultural characteristics of the dominant visitor profile, and subsequent attitudes expressed by both individual residents and the "community at large" have been presented as contributing elements to a generic and broadly specified theory of tourism's primary costs and benefits as summarized in the final column of Table 1 . Thus, as destinations continued to develop along with a continued expansion of world-wide tourism, some reasonably consistent principles have become accepted as germane to the underlying resident-visitor relationship. In this respect, local residents of high profile tourism destinations are frequently judged to have:

- A sound understanding of tourism's contribution to the local economy.

- A less accurate understanding of tourism's relative economic importance.

- Difficulty in identifying personal benefits —-what's in it for me? 
- An appreciation of tourism's contribution to improved community infrastructure and services.

- A perception of tourism as a negative influence over environmental purity.

- A perception of tourism as a positive influence over local society and lifestyle.

- Considerable faith in local planners' ability to successfully manage tourism.

- An overall marginally positive attitude to further tourism development.

However, given the tourism-intensive sites in which these previous investigations were conducted, it is relevant to speculate on whether similar results would necessarily have been obtained had the research been carried out prior to the advent of any significant tourist activity. Would the same portfolio of principles hold true, even though the physical and environmental surroundings were different? Would local attitudes towards visitors change in a circumstance where tourist activity was much less prominent, where the community in general did not fully understand the extent of their influence? These are the questions that have underpinned the overall approach to the research described in this paper.

\section{Method}

Though there have been a number of well-received attempts to develop an authoritative assessment scale to measure community attitudes to tourism-notably those developed by Lankford \& Howard (1993), and Ap \& Crompton (1998)—it was decided to reject the use of these and similar scales in favor of a direct test of respondents' level of agreement with each of the eight principles of resident attitude identified earlier. This approach was adopted to reflect a belief that the current research did not set out to gather resident opinion per se; rather it set out to assess

\section{Table}

the attitudes and beliefs of a range of case study communities in comparison with a synthesis of attitudes and beliefs established by earlier research. In effect, the primary objective of the research was to gather resident opinion in a range of communities that were NOT well known for their appeal to visitors, and to subsequently compare those opinions with the assessed view of tourist destination community residents as discussed in the previous section. As such, the advantages of simplicity offered by a brief eight item survey were thought to outweigh the greater levels of reliability available through application of a more complex instrument.

Each of the previously identified "principles of resident opinion" was initially translated into a direct attitude statement as presented below, with potential responses guided by a seven point Likert scale that was anchored by " completely disagree” as score option 1 and “completely agree”, as score option 7.

- Visitors make a valuable contribution to the local economy.

- $\quad$ Our visitor industry is just as important as other industries to our economy.

- Visitors to our community increase individual residents’ wealth.

- Visitors to our community help provide improved local facilities. 


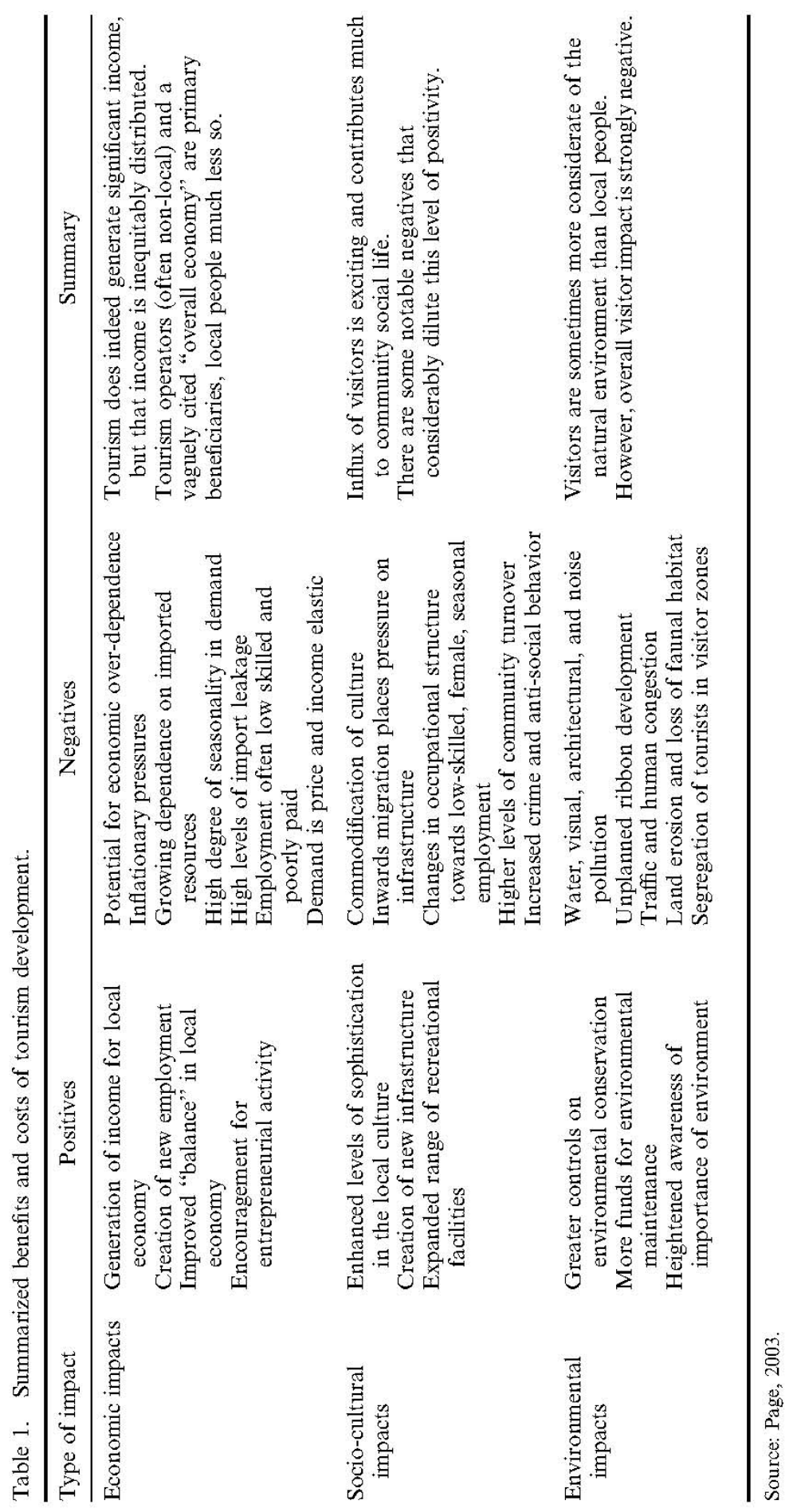


- Visitors to our community have a positive effect on the natural environment.

- Visitors to our community have a positive effect on our local lifestyle.

- Careful planning of visitation to our community can overcome possible negative effects.

- We should encourage more visitors.

These eight statements were then incorporated into a paper survey instrument, with the addition of demographic questions relating to length of community residence, gender, age, education level, personal participation in a tourism-related occupation, and income. The survey was pre-tested for potential ambiguity with a small convenience sample of the researchers' colleagues and students, before implementation in four study sites in England, Ireland, Australia and New Zealand. The Irish and New Zealand versions of the survey were mailed to 1000 individuals randomly selected from the local register of electors, with a request to complete and return within a ten day time span. The survey was accompanied by a reply-paid return envelope, and an incentive to complete was offered in the form of a gift of petrol vouchers to a randomly drawn respondent. In Australia, the same questions were included in a large scale annual social survey exercise, and administered by telephone interview to 400 local residents selected at random from the landline telephone directory - in order to reduce the size of the Australian sample to the (approximately) 200 targeted at the other three sites, random selection was used to discard $50 \%$ of the initial data set and to retain the remaining $50 \%$ for subsequent analysis.

At the English site, due to localized resource constraints, the survey was administered through the implementation of an intercept interview process with patrons of a major shopping mall located in the heart of the community concerned. A random sampling process was used, at a fixed spatial location within the shopping mall, to collect resident opinion over a five day period — as such, the number of completed responses is significantly lower than in the other three sites. A summary of the overall and sectional response statistics is shown in Table 2 below.

Table 2. Survey response statistics.

\begin{tabular}{lccccc}
\hline Criterion & England & Ireland & Australia & $\begin{array}{c}\text { New } \\
\text { Zealand }\end{array}$ & Overall \\
\hline Surveys completed & 147 & 217 & 207 & 211 & 782 \\
Male/female & $30 \%-70 \%$ & $46 \%-54 \%$ & $50 \%-50 \%$ & $40 \%-60 \%$ & $42 \%-58 \%$ \\
Mean age (years) & 42.12 & 43.18 & 49.61 & 52.81 & 47.63 \\
Mean education level & 2.64 & 3.07 & 3.02 & 2.89 & 2.93 \\
$\quad(1-6$ scale) & & & & & \\
Tourism-related occupation & $83 \%$ & $32 \%$ & $38 \%$ & $26 \%$ & $36 \%$ \\
Income level (1-7 scale) & 1.87 & 2.75 & 2.08 & 3.14 & 2.51 \\
\hline
\end{tabular}

Data collected via this process were evaluated through the application of SPSS software, and the following statistical processes conducted:

- Calculation of basic descriptive statistics for the sample and each sub-sample

- Calculation of mean response to each of the eight principles of resident attitude 
- Application of Analysis of Variance (ANOVA) to identify any significant opinion differences within and between resident groups

Due to the subjective nature of the authors' interpretations of the literature, as presented in Table 1, it was not possible to carry out statistically rigorous comparisons of survey data with assessed academic opinion. However, these comparisons were performed on an informal basis, and a qualitative description of the resulting outcomes is presented in a later section of the paper.

\section{Study sites}

In order to meet the overall objectives of the wider survey project, it was deemed desirable to conduct this research in four reasonably comparable communities that nevertheless reflected varying stages of tourism intensity development. As such, the communities of Buxton (England), Waterford (Ireland), Rockhampton (Australia), and Whangarei (New Zealand) were selected as broadly comparable entities. As such, all four communities are presented as market towns that act as a service center for a surrounding rural community; all four are located in relatively close proximity to major population centers; and all four are (to a degree) transit stops between those large population centers and iconic tourism destinations of international repute. A summarized comparison of site characteristics is presented in Table 3 below.

Table 3. Study site characteristics.

\begin{tabular}{|c|c|c|c|c|}
\hline Criterion & England & Ireland & Australia & New Zealand \\
\hline Study Site & Buxton & Waterford & Rockhampton & Whangarei \\
\hline Urban population & 25,000 & 45,000 & 65,000 & 45,000 \\
\hline Rural population & 75,000 & 30,000 & 100,000 & 25,000 \\
\hline Economic drivers & $\begin{array}{c}\text { Agriculture, } \\
\text { tourism }\end{array}$ & $\begin{array}{l}\text { Agriculture, light } \\
\text { manufacturing }\end{array}$ & $\begin{array}{l}\text { Mining, } \\
\text { agriculture }\end{array}$ & $\begin{array}{l}\text { Agriculture, light } \\
\text { manufacturing }\end{array}$ \\
\hline $\begin{array}{l}\text { Relative } \\
\text { prosperity }\end{array}$ & Moderate & Moderate & Moderate & Moderate \\
\hline $\begin{array}{l}\text { Iconic visitor } \\
\text { attractions }\end{array}$ & $\begin{array}{l}\text { High Peak } \\
\text { National Park }\end{array}$ & $\begin{array}{c}\text { Waterford } \\
\text { Crystal }\end{array}$ & None & None \\
\hline $\begin{array}{l}\text { Nearby urban } \\
\text { conurbations }\end{array}$ & $\begin{array}{l}\text { Several, approx. } \\
\text { population } \\
15 \text { million }\end{array}$ & $\begin{array}{c}\text { Dublin, } 1.6 \\
\text { million }\end{array}$ & $\begin{array}{l}\text { Brisbane, } \\
1.8 \text { million }\end{array}$ & $\begin{array}{l}\text { Auckland, } \\
1.4 \text { million }\end{array}$ \\
\hline $\begin{array}{l}\text { Nearby tourism } \\
\text { icons }\end{array}$ & Several & Ring of Kerry & $\begin{array}{l}\text { Great Barrier } \\
\text { Reef }\end{array}$ & Bay of Islands \\
\hline $\begin{array}{l}\text { Level of tourism } \\
\text { activity }\end{array}$ & High & Moderate to low & Low & Low \\
\hline
\end{tabular}

\section{Results}

The primary descriptive statistics associated with respondent results are shown in Table 4 below, with responses to each of the eight evaluative questions shown as an overall mean and as a separate mean for each of the four study sites.

\section{Discussion}

Respondents clearly claim to understand the economic promise that tourism offers their communities, though the impact of this promise is somewhat less prominent in the Australian sample-implementation of an ANOVA over the relevant responses confirmed a statistically significant difference between the Australian data and those from the other three study sites (F 1/4 5.589, p 5 .01). Further analysis of the entire data set revealed a direct link between scores for the variables "visitors make a valuable economic contribution to the 
Table 4. Summarized results.

\begin{tabular}{lccccc}
\hline $\begin{array}{l}\text { Visitor Criterion (maximum } \\
\text { agreement }=7.00 \text { ) }\end{array}$ & Overall & England & Ireland & Australia & $\begin{array}{c}\text { Zealand } \\
\text { Zeal }\end{array}$ \\
\hline $\begin{array}{l}\text { Visitors make a valuable contribution } \\
\text { to the local economy. }\end{array}$ & 5.90 & 6.07 & 6.14 & 5.43 & 5.99 \\
$\begin{array}{l}\text { Our visitor industry is just as } \\
\text { important as other industries } \\
\quad \text { to our economy. }\end{array}$ & 5.12 & 5.28 & 5.22 & 5.10 & 4.91 \\
$\begin{array}{l}\text { Visitors to our community increase } \\
\text { individual residents' wealth }\end{array}$ & 3.80 & 4.35 & 3.75 & 3.47 & 3.81 \\
$\begin{array}{l}\text { Visitors to our community help } \\
\text { provide improved local facilities. }\end{array}$ & 4.32 & 3.80 & 4.46 & 4.38 & 4.49 \\
$\begin{array}{l}\text { Visitors to our community have a } \\
\text { positive effect on the natural } \\
\text { environment. }\end{array}$ & 5.12 & 5.01 & 5.22 & 5.12 & 5.09 \\
$\begin{array}{l}\text { Visitors to our community have a } \\
\text { positive effect on our local lifestyle }\end{array}$ & 5.16 & 5.18 & 5.18 & 5.16 & 5.13 \\
$\begin{array}{l}\text { Careful planning of visitation to our } \\
\text { community can overcome possible } \\
\text { negative effects. }\end{array}$ & 5.94 & 5.60 & 6.30 & 5.78 & 5.99 \\
\begin{tabular}{l} 
We should encourage more visitors. \\
\hline
\end{tabular} & 5.90 & 5.56 & 6.23 & 5.70 & 5.99 \\
\hline
\end{tabular}

local economy" and "we should encourage more visitors" - the Pearson coefficient for this relationship was a statistically moderate .406-and there does therefore seem to be a degree of causality between perceived economic benefits and enthusiasm for further expansion.

Interestingly, our informal prediction that respondents would under-estimate the relative economic importance of tourism to their communities was not supported in the data, though New Zealand respondents appeared rather less positive than those in the other study sites. This can of course be interpreted as a reflection of current reality, as tourism is not yet a major force in any of these communities, but can equally well be seen as a failure to recognize the full industrial-economic implications of growing non-resident activity in the area. On the other hand, respondents appear to have a pragmatically realistic set of expectations in terms of potential for improvements in their own personal wealth. Here, it is interesting to note the higher level of confidence expressed by English respondents in response to this question, attributable at least in part to these respondents' much higher levels of direct involvement with visitors - there is a statistically significant Pearson coefficient of .306 between the variables "I am employed in a tourism related occupation"” and 'Visitors to our community increase individual residents' wealth." It appears then that familiarity, in this instance at least, breeds greater understanding rather than increased contempt!

If the data does tend to suggest a reasonably accurate understanding of the ways in which economic positives may be expected to flow from increasing visitor activity, a vastly different picture emerges from resident perceptions of non-economic impacts. In the first instance, there is a significant lack of appreciation of the degree to which a healthy visitor industry demands the provision of updated recreational infrastructure, which then at least equally benefits the resident population in terms of better parks and gardens, shopping, food and beverage options, and entertainment etc. More important perhaps is the consistently positive view of tourism as an environmental and social benefactor that can be successfully managed to the elimination of negative impacts. As much of the extant literature would seem to indicate, this is by no means coincident with the past experiences of communities with higher levels of past visitor industry involvement. 
In a number of other respects though, sub-sets of respondent opinion were very much in alignment with the types of attitude expected in visitor-intensive communities. When a series of ANOVA procedures were conducted to assess the impact of demographic variables on respondent opinion, no significant variation could be attributed to respondents' years of residence in the community, gender, or income levels. However, those who claimed direct involvement with the local tourism industry were understandably more positive about industry contributions to individual wealth (F 1/4 11.222, p 5 .01), and were also more supportive of any attempts to attract more visitors (F 1/4 4.799, p 5 .01). This desire was not, however, supported by older residents ( $F^{1 / 4} 5.5506$, $p 5$.01) or the better educated ( $F^{1 / 4}$ 3.303, p 5 .01). These findings are very much in line with the experience of past researchers cited earlier in this paper, again suggesting that the level of conceptual understanding in these incidental tourism communities may in fact be relatively well developed in some respects.

Overall, although there is an obvious element of subjective interpretation involved in any such judgements, it appears possible that these communities' lack of any major past exposure to the realities of the tourism industry has permitted the evolution of a "rose coloured glasses"' perception of what tourism can do for the local community, and of what the attendant costs of these benefits might be. As such, the four study sites may already be exhibiting the classic symptoms of what Smith \& Krannich (1998) called "'hungry" communities-high economic expectations, albeit tempered with a realistic scepticism of the degree of personal benefit, allied to an apparent belief that both societal and environmental concerns can be effectively managed in the interests of minimum change.

If this is indeed the case, the likely future evolution of tourism in these communities is clearly, and not altogether positively, signposted in the literature- ' "hungry"' community attitudes drifting in a steady downwards spiral through ambivalence and into saturation, and a corresponding shift in resident attitudes from embracement to withdrawal. So what can these communities do now to avoid or at least mitigate the negatives that appear to lie ahead? One answer to this question would appear to lie with a revised response to the management of expectations, a commitment by local government and other peak body stakeholders to an objective and transparent presentation of the realities of tourism industry development—before such development becomes "official”' community policy. If this more realistic approach to representing the potential impacts of tourism is adopted, we argue that community planners' language may then be expected to move from the conventional and largely expected version represented in the left column of Table 5; and towards a more pragmatic and ultimately more honest representation presented in the right column.

Community development practice is replete with examples of local projects that have been "sold" to residents via an amalgam of established fact, inadvertent oversight, and deliberate misrepresentation, and the potential relevance of this judgement to local community tourism development is not difficult to imagine. Though it may perhaps be unfair to describe this practice as typical, the left column of typical 5 represents a by no means unusual "push"' strategy that conceptualizes tourism as a development initiative that must therefore be actively promoted to residents in pursuit of community acceptance and endorsement - an intrinsically beneficial strategy that needs only to be invested in, promoted, and subsequently tolerated by all concerned. In contrast, we argue that the right column of Table 5 represents a superior " pull”' strategy that sees tourism as a significant agent of change that will substantially alter the character of the community, and something that must therefore be carefully managed in pursuit of maximum benefit with minimum side effects - an intrinsically high risk strategy that communities cannot afford to treat with anything but the utmost care and attention. 
Table 5. Two developmental rationales for community tourism.

\begin{tabular}{|c|c|}
\hline Conventional rationale & Recommended rationale \\
\hline $\begin{array}{l}\text { Community tourism means much higher } \\
\text { levels of income flowing into the local } \\
\text { economy }\end{array}$ & $\begin{array}{l}\text { Community tourism means an increase in the } \\
\text { number of people available for local businesses } \\
\text { to market to }\end{array}$ \\
\hline $\begin{array}{l}\text { Community tourism means that } \\
\text { individuals will become more } \\
\text { prosperous }\end{array}$ & $\begin{array}{l}\text { Community tourism offers an opportunity to } \\
\text { build relationships that will be economically } \\
\text { beneficial for all organizations and individuals } \\
\text { concerned }\end{array}$ \\
\hline $\begin{array}{l}\text { Community tourism means that we will } \\
\text { need to build better local } \\
\text { infrastructure for use by residents and } \\
\text { visitors alike }\end{array}$ & $\begin{array}{l}\text { Community tourism means that we may have to } \\
\text { rethink our infrastructural development } \\
\text { priorities, and to assess the positives and } \\
\text { negatives that reprioritization implies }\end{array}$ \\
\hline $\begin{array}{l}\text { On balance, an increase in visitor } \\
\text { numbers will have a negligible impact } \\
\text { on our natural environment }\end{array}$ & $\begin{array}{l}\text { Visitors may have a different value system than } \\
\text { local people in relation to the natural } \\
\text { environment- the more visitors we have, the } \\
\text { greater care needs to be taken to sustain our } \\
\text { own local value system }\end{array}$ \\
\hline $\begin{array}{l}\text { On balance, an increase in visitor } \\
\text { numbers will have a positive impact } \\
\text { on our local lifestyle }\end{array}$ & $\begin{array}{l}\text { Temporary visitors and permanent residents have } \\
\text { radically different expectations in relation to } \\
\text { lifestyle elements - the more visitors we have, } \\
\text { the greater care needs to be taken to sustain our } \\
\text { own local value system }\end{array}$ \\
\hline $\begin{array}{l}\text { Whatever the benefits and costs of } \\
\text { increased community tourism, } \\
\text { damage to our community can be } \\
\text { minimized or eliminated by careful } \\
\text { local government planning }\end{array}$ & $\begin{array}{l}\text { Commitment to increased levels of community } \\
\text { tourism places ever greater demands on local } \\
\text { planners to exhibit high levels of professional } \\
\text { care and attention in a largely unfamiliar } \\
\text { planning milieu }\end{array}$ \\
\hline
\end{tabular}

The enhanced degree of honesty, transparency, and equity that characterizes the right column of Table 5 constitutes, to us, the most persuasive argument for its adoption. On the one hand, residents who are more accurately aware of what lies ahead for any given community venture are more likely to offer informed opinions on that venture's desirability, exhibit enhanced levels of participation and ownership, and commit to high level determination to succeed. More pragmatically, and whatever the motivation, it is the opinion of the current authors that the right side of Table 5 is, in fact, a much more effective "selling" proposition than the more commonly evident advocacy position reflected in the left column - telling the truth, the whole truth, and nothing but the truth remains as powerful a strategy as it ever has been.

\section{Conclusions}

This paper has investigated the extent to which local communities on the brink of committing to the development of a tourism industry are fully aware of the conventionally accepted ramifications of such a move. In summary, the authors propose that such communities are frequently encouraged to enter into such an activity by the (involuntary or deliberate) promise of high level economic benefit, accompanied by manageable social and environmental change. It is further suggested that communities who accept this equation as an accurate representation of what they might reasonably expect from tourism are largely doomed to disappointment-tourism is infinitely more complex than a simple economic equation might suggest, and early acceptance and understanding of this reality is a useful contributor to enhanced prospects of successful industry development in the community.

For local community administrations, the essential message-commitment to over-promise and under-delivery- is a simple though superficially challenging proposition to adopt. It has traditionally been accepted practice for local government and other development project sponsors to err on the side of optimism when presenting a rationale for developmental direction change-however, it is the central contention of this paper that this 
may be a short sighted approach that greatly enhances the possibility of ultimate disappointment whilst doing little or nothing to enhance local community support for the project in question. If this is indeed the case, we urge local government administrations in those communities who currently qualify as "incidental destinations"' to consider their options extremely carefully, and to ensure that they and their residents are fully acquainted with the past history of local tourism development, before electing to invest scarce local resources in this most intricately complex of activities. The rewards of success are by no means clearly established, but the penalties of failure have been writ large for all to see.

\section{References}

Addison, L. (1996). An approach to community based tourism planning in the Baffin region, Canada's Far North. In L.C. Harrison \& W. Husbands (Eds.) Practising responsible tourism: International case studies in tourism planning, policy and development. New York: John Wiley \& Sons.

Akis, S., Peristianis, N., \& Warner, J. (1996). Residents' attitudes to tourism development: The case of Cyprus. Tourism Management, 17(7), 481-494.

Ap, J., \& Crompton, J.L. (1998). Developing and testing a tourism impact scale. Journal of Travel Research, 37(2), 120-130.

Blackstock, K. (2005). A critical look at community based tourism. Community Development Journal, 40(1), 39-49.

Bramwell, B., \& Sharman, A. (1999). Collaboration in local tourism policy making. Annals of Tourism Research, 26(2), 392-415.

Choi, H.C., \& Sirakaya, E. (2006). Sustainability indicators for managing community tourism. Tourism Management, 27, 1274-1289.

Coetzee, J.M. (1980). Waiting for the Barbarians. London: Secker and Warburg.

De Beer, F., \& Marais, M. (2005). Rural communities, the natural environment and development some challenges, some successes. Community Development Journal, 40(1), 50-61.

Di Stefano, D. (2004). Tourism, industry, and community development: Whitefish, Montana, 1903-2003. Environmental Practice, 6(1), 63-70.

Fleischer, A., \& Felsenstein, D. (2000). Support for rural tourism: Does it make a difference? Annals of Tourism Research, 27(4), 1007-1024.

Gotham, K.F. (2005). Tourism from above and below: Globalisation, localisation, and New Orleans' Mardi Gras. International Journal of Urban and Regional Research, 29(2), 309-326.

Hall, C.M., \& Lew, A.A. (1998). Sustainable tourism - a geographical perspective. New York: Addison Wesley Longman.

Hardy, A.L., \& Beeton, R.J.S. (2001). Sustainable tourism or maintainable tourism: Managing resources for more than average outcomes. Journal of Sustainable Tourism, 9(3), 168-192.

Hommen, L., Doloreux, D., \& Larsson, E. (2006). Emergence and growth of Mjarvedi Science Park in Linkoping, Sweden. European Planning Studies, 14(10), 1331-1361.

Lankford, S.V., \& Howard, D.R. (1993). Developing a tourism impact attitude scale. Annals of Tourism Research, 21(1), 121-139.

Liu, J.C., \& Var, T. (1986). Resident attitudes towards tourism impacts in Hawaii. Annals of Tourism Research, 13, 193-214. 
Marcinczak, S., \& van der Velde, M. (2008). Drifting in a global space of textile flows: Apparel bazaars in Poland's Lodz region. European Planning Studies, 16(7), 911-923.

Page, S. (2003). Tourism management: Managing for change. Amsterdam: Butterworth-Heinemann.

Pearce, D.G. (1989). Tourism development. Hartlow: Longman.

Phillips, R. (2004). Artful business: Using the arts for community economic development. Community Development Journal, 39(2), 112-122.

Sautter, E.T., \& Leisen, B. (1999). Managing stakeholders: A tourism planning model. Annals of Tourism Research, 26(2), 312-328.

Simpson, M.C. (2007). An integrated approach to assess the impacts of tourism on community development and sustainable livelihoods. Community Development Journal, 44(2), 186-208.

Smith, M.D., \& Krannich, R.S. (1998). Tourism dependence and resident attitudes. Annals of Tourism Research, 25(4), 783-8702.

Snaith, T., \& Haley, A. (1999). Residents' opinions of tourism development in the historic city of York, England. Tourism Management, 20(1), 595-603.

Switzer, C. (2001). Waiting for the Barbarians Review. Turtleneck - an online journal of literary culture. Retrieved on 10 October 2009 from http://turtleneck.net/summer01/ tweedjacket/coetzee2.htm

Theodori, G.L. (2005). Community and community development in resource-based areas: Operational definitions rooted in an international perspective. Society and Natural Resources, 18, 661-669.

Tomljenovic, R., \& Faulkner, W. (1999). Tourism and older residents in a sunbelt resort. Annals of Tourism Research, 27(1), 93-114.

Weaver, D., \& Lawton, L (2002). Tourism management (2nd ed.). Milton, Australia: John Wiley and Sons.

Yigitcanlar, T., \& Velibeyoglu, K. (2008). Knowledge based urban development: The local development path of Brisbane, Australia. Local Economy, 23(3), 195-207.

Zhang, J., Inbakaran, R.J., \& Jackson, M. (2006). Regional community attitudes towards tourism: identification of community clusters in Murrindini Shire, Victoria. Proceedings of $16^{\text {th }}$ annual CAUTHE conference. Melbourne, 6-9 February, pp. 1257-1271. 